Acta Agroph., 2018, 25(2), 175-183

doi: $10.31545 /$ aagr/92546

\title{
MORPHOLOGICAL CHARACTERISTICS AND NUTRITIONAL VALUE OF PURPLE-COLOURED STORAGE ROOTS OF CARROTS PROTECTED WITH A BIOFUNGICIDE
}

\author{
Joanna Majkowska-Gadomska, Artur Dobrowolski, Emilia Mikulewicz \\ Department of Horticulture, Faculty of Environmental Management and Agriculture \\ University of Warmia and Mazury in Olsztyn, Poland \\ e-mail: majkowska-gadomska@uwm.edu.pl
}

\begin{abstract}
A field experiment was conducted in 2013-2014. The experiment had a randomised block design with three replicates. The first experimental factor was two carrot (Daucus carota $\mathrm{L}$.) cultivars, 'Purple Haze $\mathrm{F}_{1}$ ' and 'Deep Purple $\mathrm{F}_{1}$ ', and the second experimental factor was the application of the biocontrol agent Bioczos BR. In the control treatment, plots were sprayed with water. The aim of the study was to determine the effect of Bioczos BR on selected morphological traits and the nutritional value of purple-coloured storage roots of carrots. The analysed carrot cultivars differed considerably in root weight and length. Carrots of cv. 'Deep Purple $F_{1}$ ' had higher average root weight. Consistent changes were observed in the nutrient content of carrot roots. Bioczos BR contributed to an increase in the content of dry matter (by 14\%), total sugars (by 28\%), reducing sugars (by $31 \%$ ) and nitrates (V) (by 32\%) in carrot roots, in comparison with the control treatment.

Keyw ords: carrots, morphology, nutritional value, storage roots
\end{abstract}

\section{INTRODUCTION}

Carrots (Daucus carota L.) are one of the most popular root vegetables grown worldwide. According to Arscott and Tanumihardja (2010), Wierzbicka and Majkowska-Gadomska (2012), the consumption of carrots has been increasing steadily in recent years because they are a rich source of nutrients, including antioxidants. Carrot cultivars with purple roots, which are relatively uncommon in Europe, provide considerable health benefits (Czapski et al. 2009).

There is a growing interest among consumers in organic crops (Jamiołkowska and Hetman 2016). Therefore, vegetable growers and producers have to optimise production technologies with the use of biocontrol agents that improve the quality and yield of vegetables, and increase the productivity of horticultural crops (Calvo 
et al. 2014, Pytlarz-Kozicka and Zagórski 2012). According to Jamiołkowska and Hetman (2016) biological preparations protect plants against pathogens and induce various resistance mechanisms in the plants. A good biopreparation in plant protection is Bioczos BR. The preparation Bioczos BR is based on natural garlic pulp. Garlic extract has antifungal and antibacterial properties. The antimicrobial activity of garlic juice is due to allicin. Allicin is a natural biological substance, a phytoanticipin produced in garlic upon wounding (Jamiołkowska and Wagner 2011).

The objective of this study was to determine the effect of the biofungicide Bioczos BR on selected morphological traits and the nutritional value of purplecoloured storage roots of carrots.

\section{MATERIAL AND METHODS}

Two carrot cultivars with purple-coloured storage roots were grown in a twofactorial experiment conducted in 2013-2014 in the Experimental Garden owned by the University of Warmia and Mazury in Olsztyn. The experiment had a randomised block design with three replicates. The first experimental factor was two carrot cultivars, 'Purple Haze $F_{1}$ ' and 'Deep Purple $F_{1}$ ' from Johnny's Selected Seeds. The second experimental factor was the application of the biocontrol agent Bioczos BR at $2.5 \%$. In the control treatment, plots were sprayed with water. The effect of Bioczos BR on the morphological traits and nutrient content of carrot roots was determined. Carrots were grown on ridges, in the second year after manure application, on brown soil of quality class $\mathrm{IVb}$, with $\mathrm{pH} 7.3$, salt concentration

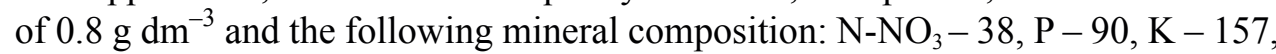
$\mathrm{Ca}-1840, \mathrm{Mg}-194 \mathrm{mg} \mathrm{dm}^{-3}$. Soil mineral deficiencies were corrected based on chemical analysis. Carrots were grown after cruciferous vegetables. Each year, carrot seeds were sown in the middle of May, at ridge spacing of $65 \mathrm{~cm}$. Plot size was $7.5 \mathrm{~m}^{2}$. Bioczos BR was applied three times, at 10-day intervals, beginning at 2 weeks after seedling emergence. The Bioczos preparation was applied in the form of spraying at a concentration of 3\%. Carrot plants were cultivated in line with the generally observed standard for this vegetable species. Each year, once-over harvest of carrot roots was carried out in the middle of October. The roots were divided into fractions of total yield, representing marketable and non-marketable yields, according to the relevant commercial quality standards (Commission Regulation (EC) No. 46/2003). Ten carrot roots were sampled from the marketable yield to prepare average samples in each treatment. The weight, length and width of root and the horizontal diameter of the core were determined at the height of $2 \mathrm{~cm}$ from the root head. The chemical composition of carrot roots was analysed in the laboratory by determining the content of dry matter - by drying the samples at $105^{\circ} \mathrm{C}$ to constant weight (PN90/A-75101/03), total sugars and reducing sugars - by the 
method proposed by Luff-Schoorl (PN-90/A-75101/07), L-ascorbic acid - by the method proposed by Tillmans and modified by Pijanowski (Determination of vitamin C content... PN-90/A-75101/11), nitrates (V) - colorimetrically, with the use of salicylic acid (Krauze and Domska 1991).

The influence of the experimental factors in both years of research was similar, therefore the results were averaged. The analyses were performed in 3 replicates, and the results were processed statistically by analysis of variance (ANOVA) in the STATISTICA 12 program. The significance of differences between means was estimated by Tukey's range test at $\alpha=0.05$.

\section{RESULTS AND DISCUSSION}

Research has shown that biopreparations can contribute to improving the health status and quality of horticultural crops (Sapieha-Waszkiewicz et al. 2010). According to Regulation (EC) No 1107/2009 of the European Parliament and of the Council (Regulation (EC)... 2009), integrated crop protection strategies should involve non-chemical control methods and natural alternative plant protection products. The biocontrol agent Bioczos BR containing paraffin-coated garlic pulp has been found to be highly effective in protecting plants and improving the chemical composition of the edible parts of vegetables (Wierzbicka and Majkowska-Gadomska 2012). The preparation is used to control bacterial and fungal diseases, and pest infestations in vegetable crops (Janas et al. 2002, Dłużniewska 2004). According to Sapiecha-Waszkiewicz et al. (2010), Bioczos BR can be applied at all growth stages of plants, starting from germination, through emergence to the end of vegetative growth and maturity. The high effectiveness of Bioczos BR has been demonstrated in many studies (Saniewska 2004, Sealy et al. 2007, Jemiołkowska and Wagner 2011, Hadian 2012, Jamiołkowska and Hetman 2016). Sapiecha-Waszkiewicz et al. (2010) found that the product had a toxic effect on the spore germination of pathogenic fungi. Horoszkiewicz-Janka et al. (2012) reported low infection rates in legume seeds treated with garlic pulp whose effect was comparable with that of chemical dressing. In a study by Sapiecha-Waszkiewicz et al. (2010), the biofungicide Bioczos Standard protected strawberries against gray mould, and its effectiveness was largely affected by weather conditions. Heavy rainfall during the growing season reduced the effectiveness of Bioczos BR.

The present study revealed significant differences in the biometric parameters and chemical composition of purple-coloured storage roots of two carrot cultivars. Bioczos BR had a significant effect on root morphology (Table 1). According to Wierzbicka et al. (2010) and Majkowska-Gadomska et al. (2007), the yield and quality of carrot roots are determined by weather conditions, the selection of appropriate varieties and adequate agronomic conditions. 
Table 1. The effect of cultivar and of the biocontrol agent Bioczos BR on the biometric characteristics of carrot storage roots (means of 2013-2014)

\begin{tabular}{|c|c|c|c|c|c|}
\hline \multirow[t]{2}{*}{ Cultivar } & \multirow{2}{*}{$\begin{array}{c}\text { Method } \\
\text { of protection }\end{array}$} & Mass & Root length & Root width & $\begin{array}{c}\text { Horizontal diameter } \\
\text { of the core }\end{array}$ \\
\hline & & g & \multicolumn{3}{|r|}{ 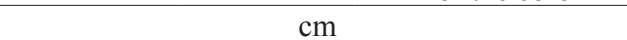 } \\
\hline \multirow{2}{*}{ Purple Haze $F_{1}$} & Control & 60.43 & 19.10 & 2.18 & 1.98 \\
\hline & Bioczos BR & 65.84 & 18.28 & 3.10 & 2.82 \\
\hline Mean & & 63.14 & 18.69 & 2.64 & 2.40 \\
\hline \multirow{2}{*}{ Deep Purple $F_{1}$} & Control & 156.77 & 26.27 & 2.60 & 2.53 \\
\hline & Bioczos BR & 172.53 & 22.70 & 3.25 & 3.02 \\
\hline Mean & & 164.65 & 24.48 & 2.92 & 2.77 \\
\hline \multirow{2}{*}{ Mean } & Control & 108.60 & 22.68 & 2.39 & 2.25 \\
\hline & Bioczos BR & 119.19 & 20.49 & 3.17 & 2.92 \\
\hline \multicolumn{6}{|l|}{$\operatorname{LSD} \alpha=0.05$} \\
\hline \multicolumn{2}{|l|}{ Cultivar } & 10.86 & 2.33 & n.s. & n.s. \\
\hline \multicolumn{2}{|c|}{ Method of protection } & n.s. & n.s. & 0.73 & 0.64 \\
\hline \multicolumn{2}{|c|}{ Interaction } & 11.60 & 2.38 & n.s. & n.s. \\
\hline
\end{tabular}

Statistical analysis of the mean values of the analysed parameters, determined over the two-year study, revealed that the weight and length of carrot roots were significantly affected by cultivar and the interaction between the experimental factors. Carrot roots of cv. 'Deep Purple $\mathrm{F}_{1}$ ' treated with Bioczos BR had the highest weight, and carrot roots of $\mathrm{cv}$. 'Purple Haze $\mathrm{F}_{1}$ ' grown in the control treatment had the lowest weight. The weight of carrot roots noted in this study is similar to the values reported by Majkowska-Gadomska et al. (2007) (117.2 to $272.1 \mathrm{~g}$ for various cultivars) and by Kozik et al. (2011) (60.0-140.0 g).

Significant differences in root length were also observed in our study. Carrot roots of cv. 'Deep Purple $F_{1}$ ' were longer than carrot roots of cv. Purple Haze $F_{1}$ '. Carrots of cv. 'Deep Purple $\mathrm{F}_{1}$ ' grown in the control treatment had the longest roots, and carrots of cv. 'Purple Haze $\mathrm{F}_{1}$ ' treated with Bioczos BR and grown in the control treatment had the shortest roots. Similar results were reported by Gruszecki and Łopucka (2014) (16.1-17.8 cm), and Majkowska-Gadomska et al. (2007) (18.2$24.4 \mathrm{~cm}$ ). In a study by Kozik et al. (2011), the length of carrot roots ranged from 14.8 to $22.8 \mathrm{~cm}$.

Significant differences were noted in the width of carrot roots treated with Bioczos BR and carrot roots from the control treatment. According to MajkowskaGadomska et al. (2007), the weight of carrot storage roots ranges from 3.0 to $5.2 \mathrm{~cm}$. Similar values were reported by Kozik et al. (2011) (2.50-3.30 cm). Significant differences were also found in the horizontal diameter of the core, which varied from $2.25 \mathrm{~cm}$ in the control treatment to $2.92 \mathrm{~cm}$ after the application of Bioczos 
BR. The interaction between the experimental factors had no significant effect on the horizontal diameter of the core. Similar values were reported by MajkowskaGadomska et al. (2007) (1.3-2.8 cm).

Boskovic and Rakocevic et al. (2007) and Majkowska-Gadomska and Wierzbicka (2010) demonstrated that the chemical composition of carrot roots may vary widely depending on environmental conditions. The nutrient content of purple-coloured storage roots of two carrot cultivars is presented in Table 2.

Table 2. The effect of cultivar and of the biocontrol agent Bioczos BR on nutrient content of carrot storage roots (means of 2013-2014)

\begin{tabular}{|c|c|c|c|c|c|c|}
\hline \multirow{2}{*}{ Cultivar } & \multirow{2}{*}{$\begin{array}{l}\text { Method of } \\
\text { protection }\end{array}$} & Dry matter & $\begin{array}{c}\text { Total } \\
\text { sugars }\end{array}$ & $\begin{array}{c}\text { Reducing } \\
\text { sugars }\end{array}$ & \multirow{2}{*}{ 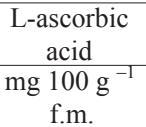 } & \multirow{2}{*}{$\begin{array}{c}\text { Nitrates }(\mathrm{V}) \\
\mathrm{mg} \mathrm{N0}_{3} \mathrm{~kg}^{-1} \text { f.m. }\end{array}$} \\
\hline & & $\%$ & \multicolumn{2}{|c|}{ 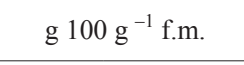 } & & \\
\hline \multirow{2}{*}{ Purple Haze $F_{1}$} & Control & 10.25 & 5.85 & 2.75 & 2.00 & 204.80 \\
\hline & Bioczos BR & 12.83 & 7.36 & 3.87 & 2.10 & 285.20 \\
\hline Mean & & 11.54 & 6.60 & 3.31 & 2.05 & 245.00 \\
\hline \multirow{2}{*}{ Deep Purple $F_{1}$} & Control & 13.08 & 5.48 & 2.81 & 2.00 & 187.20 \\
\hline & Bioczos BR & 13.69 & 7.21 & 3.45 & 2.10 & 235.30 \\
\hline Mean & & 13.38 & 6.34 & 3.13 & 2.05 & 211.25 \\
\hline \multirow{2}{*}{ Mean } & Control & 11.66 & 5.66 & 2.78 & 2.00 & 196.00 \\
\hline & Bioczos BR & 13.25 & 7.28 & 3.66 & 2.10 & 260.25 \\
\hline \multicolumn{7}{|l|}{$\operatorname{LSD} \alpha=0.05$} \\
\hline Cultivar & & 1.51 & n.s. & n.s. & n.s. & n.s. \\
\hline Method of protection & & 1.61 & 1.41 & 0.59 & n.s. & 27.51 \\
\hline Interaction & & 1.05 & n.s. & n.s. & n.s. & 13.24 \\
\hline
\end{tabular}

The dry matter content of carrot roots reached $11.54 \%$ in cv. 'Purple Haze $\mathrm{F}_{1}$ ' and $13.38 \%$ in cv. 'Deep Purple $\mathrm{F}_{1}$ ', and it was significantly affected by protection method. The roots of carrots treated with Bioczos BR had higher dry matter content. The dry matter content of carrot roots in the control treatment was approximately $12 \%$ lower. A similar value $(12.54 \%)$ was reported by Gajewski et al. (2007), Dobrzański et al. (2008), Majkowska-Gadomska and Wierzbicka (2010) and Roszkowska et al. (2015) who also analysed carrots with purple roots.

Carrot roots differed in their content of total sugars which was higher in cv. 'Deep Purple $F_{1}$ ' than in cv. 'Purple Haze $F_{1}$ '. A significant correlation was found between the applied protection method and the total sugar content of carrot roots. The application of Bioczos BR increased the concentration of total sugars in carrot roots by $28 \%$ relative to the control treatment. Similar values were noted by Wrzodak and Elkner (2010) who compared the quality of carrot roots in organic

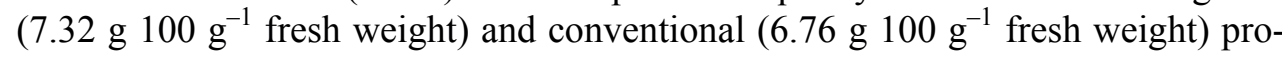
duction systems. In a study by Roszkowska et al. (2015), the average total sugar content of carrots with orange-coloured and purple-coloured roots was 5.22 and 


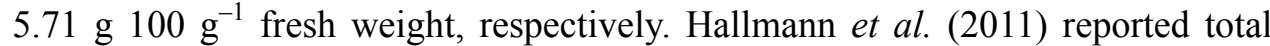

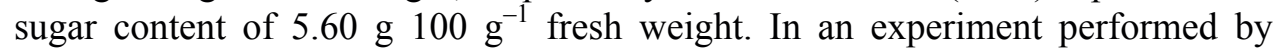
Zadernowski et al. (2010), the total sugar content of carrots with dark-coloured roots reached $7.00 \mathrm{~g} 100 \mathrm{~g}^{-1}$ fresh weight.

The application of Bioczos BR led to an increase in the content of reducing

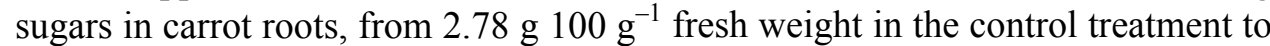

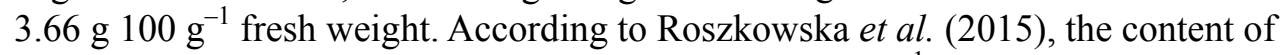

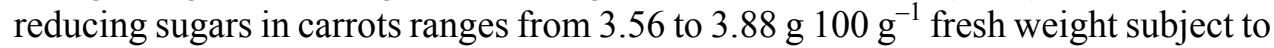
cultivar, and it is higher in carrots with purple-coloured roots. Similar observations were made by Kreutzmann et al. (2008).

Neither the experimental factors nor their interaction significantly influenced L-ascorbic acid content of carrot roots. In 2013-2014, the average concentration of L-ascorbic acid reached $2.05 \mathrm{mg} 100 \mathrm{~g}^{-1}$ fresh weight in both analysed cultivars. The values noted in this study are lower than those reported by other authors. In carrots with orange-coloured roots, analysed by Sikora et al. (2009), L-ascorbic acid levels ranged from 3.98 to $4.91 \mathrm{mg} 100 \mathrm{~g}^{-1}$ fresh weight. In an experiment conducted by Zadernowski et al. (2010), L-ascorbic acid content of black carrots

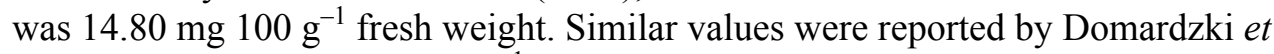
al. (2010) (1.00-34.00 mg $100 \mathrm{~g}^{-1}$ fresh weight). According to the cited authors, the concentration of L-ascorbic acids in carrot roots is mostly determined by cultivar, environmental conditions and agronomic factors. Nawirska and Król (2004) observed a nearly two-fold difference in L-ascorbic acid levels between the examined carrot cultivars, pointing to varietal variations in this parameter.

In the present study, the concentration of nitrates $(\mathrm{V})$ in carrot roots did not exceed the maximum permissible levels (Commission Regulation (EU)... 2011). Nitrate (V) content of edible carrot parts was $211.25 \mathrm{mg} \mathrm{NO}_{3}^{-} \mathrm{kg}^{-1}$ fresh weight in cv. 'Deep Purple $\mathrm{F}_{1}$ ' and $245.00 \mathrm{mg} \mathrm{NO}^{-} \mathrm{kg}^{-1}$ fresh weight in cv. 'Purple Haze $\mathrm{F}_{1}$ ', and the noted difference was statistically significant. A significant correlation was found between the applied protection method and nitrate (V) concentrations in carrot roots. The roots of carrots grown in the control treatment had a significantly lower content of nitrates (V) (196.00 $\mathrm{mg} \mathrm{NO}_{3}^{-} \mathrm{kg}^{-1}$ fresh weight) than the roots of carrots treated with Bioczos BR (260.25 mg NO${ }_{3}^{-} \mathrm{kg}^{-1}$ fresh weight). The levels of nitrates (V) in carrot roots were also significantly affected by the interaction between the experimental factors, and ranged from 187.20 to $285.20 \mathrm{mg} \mathrm{NO}_{3}^{-} \mathrm{kg}^{-1}$ fresh weight. According to Gajewska et al. (2009), the concentration of nitrates (V) in carrots varies from 42.8 to $455.0 \mathrm{mg} \mathrm{NO}_{3}^{-} \mathrm{kg}^{-1}$ fresh weight. In a study by Czerwińska and Zagóra (2011) nitrate (V) content of carrot roots was $366.49 \mathrm{mg} \mathrm{NO}_{3}^{-} \mathrm{kg}^{-1}$ fresh weight. 


\section{CONCLUSIONS}

1. Carrots of cv. 'Deep Purple $F_{1}$ ' were characterised by higher average weight, length and width of storage roots, and a larger horizontal diameter of the core than carrots of cv. 'Purple Haze $\mathrm{F}_{1}$ '.

2. The biocontrol agent Bioczos BR contributed to an increase in the mass, width of the roots and horizontal diameter of the core in carrot roots.

3. The biocontrol agent Bioczos BR contributed to an increase in the content of dry matter, total sugars, reducing sugars, L-ascorbic acid and nitrates (V) and a decrease in the concentrations of organic acids in carrot roots, in comparison with the control treatment.

4. Bioczos BR significantly increased the content of nitrates $(\mathrm{V})$ in the storage roots of the analysed carrot cultivars.

\section{REFERENCES}

Arscott S.A., Tanumihardja S.A., 2010. Colors provide basic nutrition and bioavailable phytochemicals acting as a functional food. Compr. Rev. Food Sci. Food Saf., 9(2), 223-239, doi:10.1111/j.1541-4337.2009.00103.x

Boskovic-Rakocevic L., Pavlovic R., Zdravkovic J., Zdravkovic M., Pavlovic N., Djuric M., 2012. Effect of nitrogen fertilization on carrot quality. Afr. J. Agric. Res., 7(18), 2884-2900, doi:10.5897/ AJAR11.1652

Calvo P., Nelson L., Kloepper J.W., 2014. Agricultural uses of plant biostimulants. Plant Soil, 383, 3-41, doi:10.1007/s11104-014-2131-8

Commission Regulation (EU) No 1258/2011 of 2 December 2011 amending Regulation (EC) No $1881 / 2006$ as regards maximum levels for nitrates in foodstuffs.

Czapski J., Kidoń M., Olejnik A., Witrowa-Rajchert D., 2009. Purple carrots as a raw material for fruit and vegetable processing. Przem. Ferm. Owoc.-Warz., 53(1), 31-33.

Czerwińska E., Zagóra K. 2011. Changes in minimum quality of processed vacuum packed carrots during storage. Rocz. Ochr. Środ., 13, 845-858.

Dłużniewska J., 2004. Activity of biopreparations in combating rosacea. Progress in Plant Protection, 44(2), 648-650.

Dobrzański A., Anyszka Z., Elkner K., 2008. Response of carrots to application of natural extracts from seaweed (Sargassum Sp.) - algaminoplant, and from leonardite - humiplant. J. Res. Appl. Agric. Engng., 53(3), 53-58.

Domaradzki P., Malik A., Wójcik W., 2010. Content of beta-carotene and vitamin C in selected carrot products. Bromat. Chem. Toksykol., 43(2), 118-123.

Gajewska M., Czajkowska A., Bartodziejska B., 2009. The content of nitrates (III) and (V) in selected vegetables on detail sale in Lodz region. Ochr. Środ. Zasob. Natur., 40, 388-395.

Gajewski M., Szymczak P., Elkner K., Dąbrowska A., Kret A., Danilcenko H., 2007 . Some aspects of nutritive and biological value of carrot cultivars with orange, yellow and purple coloured roots. Veg. Crops Res. Bull., 67, 149-161, doi:10.2478/v10032-007-0039-z

Gruszecki R., Łopucka E., 2014. Effect of plant density on the quantity and quality of carrots grown on ridges. Annales UMCS, Sec. EEE., 24(1), 16-24. 
Hadian S., 2012. Antifungal activity of some plant extracts against some plant pathogenic fungi in Iran. Asian J. Exp. Biol. Sci., 3(4), 714-718.

Hallmann E., Sikora M., Rembiałkowska E., Marszałek K., Lipowski J., 2011. The influence of pasteurization process on nutritive value of carrot juices from organic and conventional production, J. Res. Appl. Agric. Engng., 56(3), 133-137.

Horoszkiewicz-Janka J., Jajor E., Korbas M., 2012. Usage of biopreparations as seed dressing in legume cultivation. J. Res. Appl. Agric. Eng., 57(3), 162-166.

Jamiołkowska A., Hetman B., 2016. The mechanism of action of biological preparations used in plant protection against pathogens. Ann. UMCS Sec. E. Agricultura., 71(1), 13-29.

Jamiołkowska A ., Wagner A., 2011. Effect of garlic pulp (Bioczos Płynny) on some fungi pathogenic to vegetables. In: AFPP - Fourth International Conference on Non Chemical Crop Protection Methods, Lille, 8-10 march 2011, 213-220.

Janas R. Szafirowska A., Kołosowski S., 2002. The use of biopreparations in the biological protection of eggplants. Progress in Plant Protection., 42(2), 417-419.

Kozik E.U., Nowak R., Nowakowska M., Kamiński P., 2011. Evaluation of economic traits of carrot breeding lines in vegetative phase. Now. Warz., 52, 16-23.

Krauze A., Domska D., 1991. Specialist exercises in agricultural chemistry (in Polish). Wyd. ART., Olsztyn.

Kreutzmann S., Christensen L.P., Edelenbos M., 2008. Investigation of bitterness in carrots (Daucus carota L.) based on quantitative chemical and sensory analyses. Lebensm.-Wiss. Technol., 41, 193-205, doi:10.1016/j.lwt.2007.02.024

Majkowska-Gadomska J., Wierzbicka B., 2010. The yield and nutritive value of selected carrot cultivars with orange- and purple-colored storage roots. Acta. Sci. Pol., Hortorum Cultus., 9(4), 75-84.

Majkowska-Gadomska J., Wierzbicka B., Nowak M., 2007. The yield of nine industrial carrot varieties grown in the Warmia region. Rocz. AR Poznań. CCCLXXXIII, Ogrodn., 41, 559-563.

Nawirska A., Król A., 2004. Carrot. Comparison of selected chemical constituents of four varieties (in Polish). Przem. Ferm. Owoc.-Warzywny, 48(1), 25-26.

Pytlarz-Kozicka M., Zagórski P., 2012. The effect of growth bioregulators on the growth and yielding of several potato cultivars (in Polish). Mat. Konf. nt. Nasiennictwo i ochrona ziemniaka, Darłówko, May 24-25, 72-73.

Regulation (EC) No 1107/2009 of the European Parliament and of the Council of 21 October 2009 concerning the placing of plant protection products on the market and repealing Council Directives 79/117/EEC and 91/414/EEC.

Roszkowska B., Piłat B., Tańska M., 2015. Comparison on chemical composition of carrot roots of Orange, purple and white colour. Nauka Przyr. Technol., 9(4), \#59. doi:10.17306/J.NPT.2015.4.59

Saniewska A., 2004. Antifungal activity of grapefruit (Citrus paradisi) endogenic flavonoids. Zesz. Probl. Post. Nauk Roln., 496, 609-617.

Sapieha-Waszkiewicz A., Marjańska-Cichoń B., Miętkiewski R., 2010. Comparison of bio-pesticides Bioczos S, Biosept 33 SL and synthetic pesticides influence on germination on enthomopathogenic fungi spores. Ochr. Środ. i Zasob. Natur., 43, 117-125.

Sealy R., Evans M.R., Rothrock C., 2007. The effect of garlic extract and root substrate on soil-borne fungal pathogens. Hort. Technology, 17(2), 169-173.

Sikora M., Hallmann E., Rembiałkowska E., 2009. The content of bioactive compounds in carrots from organic and conventional production in the context of heart prevention. Roczn. PZH., 60(3), 217-220.

Wierzbicka B., Majkowska-Gadomska J. 2012. The effect of biological control of the carrot fly (Psila rosae) on the yield and quality of carrot (Daucus carota L.) storage roots. Acta Sci. Pol. Hortorum Cultus, 11(2), 29-39. 
Wierzbicka B., Pierzynowska-Korniak G., Majkowska-Gadomska J., 2004. The effect of cultivation and storage on the yield and firmness of the storage roots of two carrot varieties. Folia Univ. Agric. Stetin. 239, Agric., 95, 415-418.

Wrzodak A., Elkner K., 2010. Sensory quality of fresh and stored carrot from organic cultivation. Nowości Warzywnicze, 50, 93-101.

Zadernowski R., Piłat B., Czaplicki S., Ogrodowska D., 2010. Characteristics of the black carrot (Daucus carota ssp. sativus var. atrorubens Alef.). Pol. J. Nat. Sci., 25(4), 438-443, doi:10.2478/ v10020-010-0040-8

\title{
MORFOLOGIA I WARTOŚĆ ODŻYWCZA KORZENI SPICHRZOWYCH MARCHWI O FIOLETOWYM ZABARWIENIU UPRAWIANEJ Z WYKORZYSTANIEM BIOFUNGICYDU
}

\author{
Joanna Majkowska-Gadomska, Artur Dobrowolski, Emilia Mikulewicz \\ Katedra Ogrodnictwa, Wydział Kształtowania Środowiska i Rolnictwa \\ Uniwersytet Warmińsko-Mazurski w Olsztynie \\ ul. Prawocheńskiego 21, 10-957 Olsztyn \\ e-mail: majkowska-gadomska@uwm.edu.pl
}

Streszczenie. Doświadczenie polowe przeprowadzono w latach 2013-2014. Eksperymentu dokonano metodą losowych podbloków w trzech powtórzeniach. Pierwszy czynnik doświadczalny stanowiły rośliny dwóch odmian marchwi (Daucus carota L.), „Purple Haze F ” i „Deep Purple $\mathrm{F}_{1}$ ", a drugim eksperymentalnym czynnikiem było zastosowanie środka Bioczos BR do biologicznej ochrony. Obiekt kontrolny spryskiwano wodą. Celem badania było określenie wpływu preparatu Bioczos BR na wybrane cechy morfologiczne i wartość odżywczą purpurowych korzeni spichrzowych marchwi. Analizowane odmiany marchwi różniły się znacznie pod względem masy i długości korzeni. Rośliny marchwi odmiany „Deep Purple $\mathrm{F}_{1}$ ” miały wyższą średnią masę korzeni. Zaobserwowano stałe zmiany w zawartości składników odżywczych korzeni marchwi. Bioczos BR przyczynił się do wzrostu suchej masy (o 14\%), całkowitej zawartości cukrów (o 28\%), cukrów redukujących (o 31\%) i azotanów (V) (o 32\%) w korzeniach marchwi, w porównaniu do obiektu kontrolnego.

Słowa kluczowe: marchew, morfologia, wartość odżywcza, korzenie spichrzowe 